Article

\title{
Amaryllidaceae Alkaloids of Different Structural Types from Narcissus L. cv. Professor Einstein and Their Cytotoxic Activity
}

\author{
Kateřina Breiterová ${ }^{1}$, Darja Koutová ${ }^{2}{ }^{\oplus}$, Jana Maříková ${ }^{3}$, Radim Havelek ${ }^{2}$, Jiří Kuneš ${ }^{3}$, \\ Martina Majorošová ${ }^{2}$, Lubomír Opletal ${ }^{1}{ }^{\mathbb{D}}$, Anna Hošt'álková ${ }^{1}$ (D) , Jaroslav Jenčo ${ }^{1}$ (D), \\ Martina Řezáčová ${ }^{2}$ (D) and Lucie Cahlíková ${ }^{1, *(\mathbb{D})}$ \\ 1 ADINACO Research Group, Department of Pharmaceutical Botany, Faculty of Pharmacy, Charles University, \\ Heyrovského 1203, 50005 Hradec Králové, Czech Republic; breiterk@faf.cuni.cz (K.B.); \\ opletal@faf.cuni.cz (L.O.); HOSTA4AA@faf.cuni.cz (A.H.); jencoj@faf.cuni.cz (J.J.) \\ 2 Department of Medical Biochemistry, Faculty of Medicine in Hradec Králové, Charles University, \\ Šimkova 870, 50003 Hradec Králové, Czech Republic; koutova.darja@lfhk.cuni.cz (D.K.); \\ havelekr@lfhk.cuni.cz (R.H.); SeifrtovaM@lfhk.cuni.cz (M.M.); rezacovaM@lfhk.cuni.cz (M.R.) \\ 3 Department of Organic and Bioorganic Chemistry, Faculty of Pharmacy, Charles University, \\ Heyrovského 1203, 50005 Hradec Králové, Czech Republic; marikoj2@faf.cuni.cz (J.M.); \\ kunes@faf.cuni.cz (J.K.) \\ * Correspondence: cahlikova@faf.cuni.cz; Tel.: +420-495067311; Fax: +420-495067162
}

Received: 27 December 2019; Accepted: 19 January 2020; Published: 22 January 2020

\begin{abstract}
In this detailed phytochemical study of Narcissus cv. Professor Einstein, we isolated 23 previously known Amaryllidaceae alkaloids (1-23) of several structural types and one previously undescribed alkaloid, 7-oxonorpluviine. The chemical structures were identified by various spectroscopic methods (GC-MS, LC-MS, 1D, and 2D NMR spectroscopy) and were compared with literature data. Alkaloids which had not previously been isolated and studied for cytotoxicity before and which were obtained in sufficient amounts were assayed for their cytotoxic activity on a panel of human cancer cell lines of different histotype. Above that, MRC-5 human fibroblasts were used as a control noncancerous cell line to determine the general toxicity of the tested compounds. The cytotoxicity of the tested alkaloids was evaluated using the WST-1 metabolic activity assay. The growth of all studied cancer cell lines was inhibited by pancracine (montanine-type alkaloid), with $\mathrm{IC}_{50}$ values which were in the range of 2.20 to $5.15 \mu \mathrm{M}$.
\end{abstract}

Keywords: Narcissus cv. Professor Einstein; Amaryllidaceae; cytotoxicity; 7-oxonorpluviine; pancracine

\section{Introduction}

Plants from the Amaryllidaceae family have been used for centuries in folk medicine due to their therapeutic properties [1]. Plants from this family contain a distinct and still not fully explored group of alkaloids called Amaryllidaceae alkaloids (AA). They are most well known for their broad spectrum of biological properties such as antitumor [2,3], antimalarial [4], anti-inflammatory [5], antimicrobial [6], and AChE-inhibiting activities $[7,8]$. The AA are classified into 9 main structural types (crinine, galanthamine, haemanthamine, homolycorine, lycorine, montanine, narciclasine, norbelladine, and tazettine) alongside more than 10 others (plicamine, galanthindole, augustamine, graciline, etc.). These minor structure types are usually found in trace amounts and are most often represented by single alkaloids $[9,10]$. Galanthamine, a selective, competitive acetylcholinesterase inhibitor with antioxidant properties is the most important AA identified so far. It was isolated for the first time from Galanthus woronowii in the 1950s. Since 2000, when it was approved, it has been used to treat mild 
and moderate stages of Alzheimer's disease [11]. The ability of AA to reduce proliferative activity and viability of cancer cells is equally important. Numerous products of natural origin are known for their cytotoxic activity. These products are also a source of substances capable of affecting apoptosis resistance [12]. Simultaneously, the anti-invasive and anti-metastatic effects of some plant alkaloids have been described $[13,14]$. For this reason, substances of natural origin represent a valuable source of potential anticancer drugs; many AAs are very promising anticancer compounds, for example, the widely studied haemanthamine [15] and lycorine [16]. A well thought-out basic study of natural compounds can serve as a springboard for clinical therapy.

The genus Narcissus L. belongs to the monocotyledonous family Amaryllidaceae. Various species of this genus are commonly known as daffodil, narcissus, jonquil, etc. Genus Narcissus comprises about 100 wildlife species native mainly to the Mediterranean area [17]. Narcissus spp. have been long-established in traditional treatment of several cancer illnesses throughout the world. Hippocrates of Kos (460-370 B.C.), the famous Ancient Greek physician, recommended a pessary impregnated with narcissus oil to treat uterine tumors [18]. The application of narcissus oil in cancer treatment was also recorded in the Middle Ages in China, North Africa, Central America, and Arabian countries [19].

Due to the ease of natural hybridization, spreading, and naturalization, as well as extensive cultivation, the taxonomy of Narcissus spp. is quite complicated. A broad spectrum of cultivars has been bred mainly for ornamental purposes, and the International Daffodil Register contains over 27,000 names of these cultivars [20]. For commercial production of AAs, the cultivars are preferred over native species because of their availability. Some Narcissus cultivars have been already studied in detail, and a number of AAs have been isolated throughout the years [7,10,21]. From previous phytochemical studies of 40 differing Narcissus cultivars, 14 AAs were identified in the alkaloid extract of Narcissus cv. Professor Einstein [17] (see Supplementary Materials). The alkaloid extract also showed promising cytotoxic activity against different cancer cell types in a preliminary study (see section Results). The interesting bioactivities and lack of detailed phytochemical studies of N. cv. Professor Einstein led us to explore the properties and alkaloid content of this cultivar.

\section{Results}

\subsection{Isolation and Identification of Amaryllidaceae Alkaloids from N. cv. Professor Einstein}

Extensive phytochemical study of fresh bulbs of N. cv. Professor Einstein resulted in the isolation of 23 known AA (1-23), and a new alkaloid (24). The compounds were analyzed by various spectroscopic methods (GC-MS, LC-MS, and 1D and 2D NMR spectroscopy) and identified by comparison with literature data as masonine (1) [22], homolycorine (2) [23], ismine (3) [24], caranine (4) [25], galanthamine (5) [26], narwedine (6) [27], lycoraminone (7) [28], pluviine (8) [25], incartine (9) [29], galanthine (10) [30], lycoramine (11) [26], epinorgalanthamine (12) [31], norlycoramine (13) [32], haemanthamine (14) [32], hippeastrine (15) [33], epimaritidine (16) [34], lycorine (17) [35], tazettine (18) [36], eugenine (19) [37], norpluviine (20) [38], 9-O-demethylmaritidine (21) [39], pancracine (22) [40], and 9-O-demethylhomolycorine (23) [23] (Figure 1). The alkaloids that were isolated were representatives of the homolycorine $(1,2,15,19,23)$, galanthamine $(5,6,7,11,12,13)$, haemanthamine $(14,16,21)$, lycorine $(4,8,9,10,17,20)$, montanine (22), tazettine (18), and miscellaneous (3) structure types.

The structure of compound $\mathbf{2 1}$ is already known, but confirmation of it was not possible due to the absence of its NMR data in the available literature. This led us to publish the complete ${ }^{1} \mathrm{H}$ and ${ }^{13} \mathrm{C}$ NMR spectra for this alkaloid. The structural constitution was elucidated utilizing 2D experiments such as gCOSY, gHSQC, and gHMBCAD (see Figure 2). 
<smiles>[R]C1C=C2CCN([R1])[C@@]23c2cc4c(cc2C(=O)O[C@H]13)OCO4</smiles>

$\mathrm{R}=\mathrm{H}, \mathrm{R} 1=$ Me Masonine (1) $\mathrm{R}=\mathrm{OH}, \mathrm{R} 1=$ Me Hippeastrine $(15)$<smiles>COc1ccc2c3c1O[C@H]1C[C@@H](O)C=C[C@]31CCN(C)C2</smiles>

Galanthamine (5)

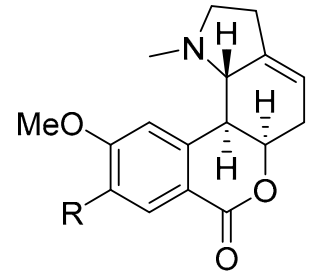

$\mathrm{R}=\mathrm{OMe}$ Homolycorine (2)<smiles>CNc1ccccc1-c1cc2c(cc1CO)OCO2</smiles>

Ismine (3)

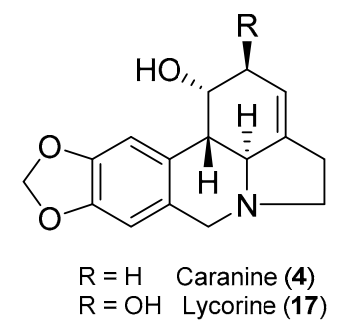<smiles>[R]N1CC[C@]23CC[C@@H](O)C[C@H]2Oc2c(OC)ccc(c23)C1</smiles>

$\mathrm{R}=\mathrm{Me} \quad$ Lycoramine (11) $\mathrm{R}=\mathrm{H} \quad$ Norlycoramine (13)<smiles>[R]c1cc2c(cc1OC)[C@@H]1[C@H](O)[C@H]([R])C=C3CCN(C3)[C@@H]21</smiles>

$\mathrm{R}=\mathrm{H}, \mathrm{R}_{1}=\mathrm{OMe} \quad$ Pluviine (8)

$\mathrm{R}=\mathrm{OMe}, \mathrm{R}_{1}=\mathrm{OMe}$ Galanthine (10)<smiles>COc1ccc2c3c1O[C@H]1CC(=O)C=C[C@@]31CCN(C)C2</smiles>

Narwedine (6)<smiles>COc1ccc2c3c1O[C@H]1CC(=O)CC[C@]31CCN(C)C2</smiles>

Lycoraminone (7)

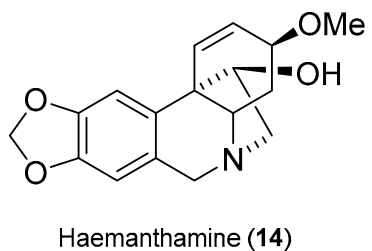

Incartine (9)<smiles>[C-]1CCCC1</smiles><smiles>COc1ccc2c3c1O[C@H]1CCC=C[C@@]31CCNC2</smiles>

Haemanthamine (14)

$\mathrm{R}=\mathrm{H}, \mathrm{R}_{1}=\mathrm{OH} \quad$ Norpluviine (20)<smiles>COc1cc2c(cc1OC)[C@@]13C=C[C@H](O)CC1(C)N(C2)C3</smiles>

Epimaritidine (16)

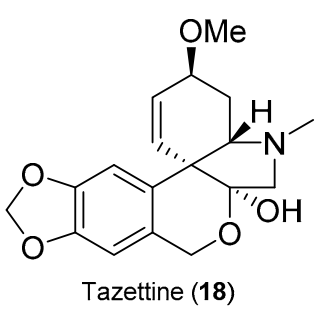

Tazettine (18)<smiles>CCOC1OC2CC=C3CCN(C)[C@@]3(C)C2c2cc(OC)c(O)cc21</smiles>

Eugenine (19)<smiles>O[C@H]1C[C@@H]2C3=C[C@H](O)[C@@H](O)C[C@@H]3N(Cc3cc4c(cc32)OCO4)C1</smiles>

Pancracine (22)<smiles>COc1cc2c(cc1O)[C@@]13C=C[C@H](O)CC1(C)N(C2)C3</smiles>

9-O-Demethylmaritidine (21)

Figure 1. Structures of isolated alkaloids.

The new lycorine-type Amaryllidaceae alkaloid 24, named 7-oxonorpluviine, was isolated as a white amorphous solid. Its HR-MS data showed a molecular ion $[\mathrm{M}+\mathrm{H}]^{+}$at $m / z 288.1242$, corresponding to the formula $\mathrm{C}_{16} \mathrm{H}_{17} \mathrm{NO}_{4}$. The ${ }^{1} \mathrm{H}$ NMR data of 24 exhibited the presence of two aromatic protons $\left(\delta_{\mathrm{H}} 7.45, \mathrm{H}-8 ; 6.99, \mathrm{H}-11\right)$, one olefinic proton $\left(\delta_{\mathrm{H}} 5.71-5.67, \mathrm{H}-3\right)$, one deshielded hydroxymethine proton $\left(\delta_{\mathrm{H}} 4.95-4.91, \mathrm{H}-1\right)$, one methoxy group $\left(\delta_{\mathrm{H}} 3.98, \mathrm{C}-10-\mathrm{OCH}_{3}\right)$, one nitrogenated methine $\left(\delta_{\mathrm{H}}\right.$ 3.53-3.47, H-11c), one deshielded methylene group with diastereotopic protons $\left(\delta_{\mathrm{H}} 3.35-3.25\right.$ and 3.06-2.98, H-5), one methine proton $\left(\delta_{\mathrm{H}} 2.84, \mathrm{H}-11 \mathrm{~b}\right)$, and two methylene groups $\left(\delta_{\mathrm{H}} 2.79-2.62\right.$ and 2.61-2.54, H-2 and H-4) (Table 1). While two protons were not detected by NMR in methanol- $d_{4}$, they should have been bound to the heteroatoms. The ${ }^{13} \mathrm{C}$ NMR spectrum exhibited 16 carbons. A 1,2,4,5-tetrasubstituted benzene ring was determined by gHMBCAD experiment. The identification was based on correlations from H-11 to C-7a $\left(\delta_{C} 117.4\right)$ and C-9 $\left(\delta_{C} 148.1\right)$, and from H-8 to C-10 ( $\delta_{C}$ 154.5) and C-11a $\left(\delta_{C} 136.5\right)$, respectively. The deshielded aromatic carbons were substituted by a hydroxyl group (C-9) and a methoxy group (C-10). The carbonyl group $C-7\left(\delta_{C} 167.6\right)$ was identified in the ${ }^{13} \mathrm{C}$ NMR spectrum; this signal was shown to be correlated with $\mathrm{H}-8$ in gHMBCAD (Figure 2). The tertiary carbon $C-11 b\left(\delta_{C} 41.9\right)$, which was correlated to $\mathrm{H}-11$, was determined as a junction point between the aromatic substructural fragment and the rest of the molecule. The gCOSY experiment of 
24 revealed cross-peaks of $\mathrm{H}-11 \mathrm{~b}$ with $\mathrm{H}-11 \mathrm{c}$ and $\mathrm{H}-1, \mathrm{H}-2$ with $\mathrm{H}-1, \mathrm{H}-3$ with $\mathrm{H}-2$ and $\mathrm{H}-11 \mathrm{c}$, and $\mathrm{H}-5$ with $\mathrm{H}-4$. These correlations determined the hexahydroindole fragment in the structure (Figure 2). In addition, the gHMBCAD experiment supported this assumption by correlations from $\mathrm{H}-1$ to $\mathrm{C}-3$ $\left(\delta_{C} 118.3\right)$, from $\mathrm{H}-1$ to $\mathrm{C}-11 \mathrm{c}\left(\delta_{\mathrm{C}} 60.9\right)$, from $\mathrm{H}-1$ to $\mathrm{C}-11 \mathrm{a}\left(\delta_{\mathrm{C}} 137.7\right)$, and from $\mathrm{H}-5$ to $\mathrm{C}-11 \mathrm{c}$. The absolute configuration could not be determined due to insufficient amount of sample. The relative configuration was established and the result was supported by NOESY experiment (see Figure 2). This suggested configuration of either $1 R, 11 \mathrm{bS}, 11 \mathrm{c} S$ or $1 S, 11 \mathrm{~b} R, 11 \mathrm{c} R$ is supported by the cross-peaks of $\mathrm{H}-11 \mathrm{~b}$ and $\mathrm{H}-1$. Moreover, no correlation of these protons with $\mathrm{H}-11 \mathrm{c}$ was detected.

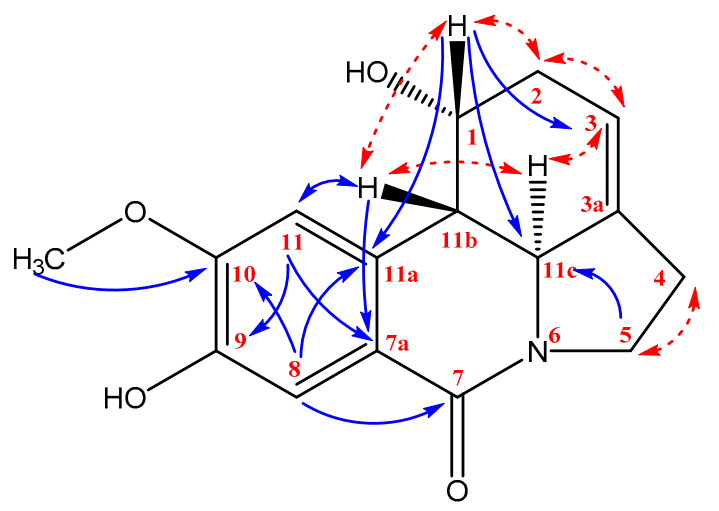

24

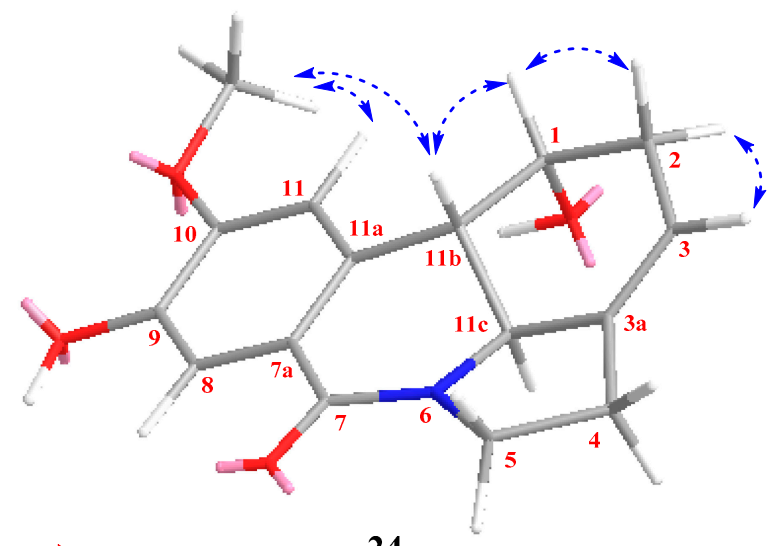

24

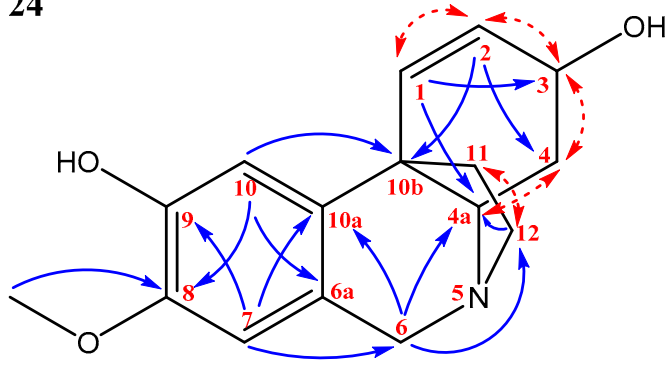

21

Figure 2. The constitution of 21; the constitution of $\mathbf{2 4}$ and its relative configuration. The key gCOSY (red dashed arrows), gHMBCAD (blue arrows), and NOESY (blue dashed arrows) correlations are marked.

Table 1. 9-O-demethylmaritidine (21) and 7-oxonorpluvine (24) ${ }^{1} \mathrm{H}$ and ${ }^{13} \mathrm{C}$ NMR data.

\begin{tabular}{|c|c|c|c|c|}
\hline \multirow{2}{*}{ Position } & \multicolumn{2}{|c|}{ 9-O-Demethylmaritidine (21) ${ }^{a}$} & \multicolumn{2}{|c|}{ 7-Oxonorpluviine (24) ${ }^{b}$} \\
\hline & $\delta_{\mathrm{C}}$ & $\delta_{\mathrm{H}}(J$ in $\mathrm{Hz})$ & $\delta_{\mathrm{C}}$ & $\delta_{\mathrm{H}}(J$ in $\mathrm{Hz})$ \\
\hline 1 & 129.0 & $6.51 \mathrm{dd}(10.2,2.2)$ & 77.3 & $4.95-4.91 \mathrm{~m}$ \\
\hline 2 & 131.1 & $5.79-5.74 \mathrm{~m}$ & 32.2 & $\begin{array}{l}2.79-2.62 \mathrm{~m} \\
2.61-2.54 \mathrm{~m}\end{array}$ \\
\hline 3 & 67.8 & $4.48-4.41 \mathrm{~m}$ & 118.3 & $5.71-5.67 \mathrm{~m}$ \\
\hline $3 a$ & - & - & 137.7 & \\
\hline 4 & 34.9 & $\begin{array}{l}2.25-2.05 \mathrm{~m} \\
1.66-1.53 \mathrm{~m}\end{array}$ & 29.5 & $2.79-2.62 \mathrm{~m}$ \\
\hline $4 a$ & 66.7 & $3.26 \mathrm{dd}(13.3,3.6)$ & - & - \\
\hline 5 & - & - & 44.9 & $\begin{array}{l}3.35-3.25 \mathrm{~m} \\
3.06-2.98 \mathrm{~m}\end{array}$ \\
\hline 6 & 61.8 & $\begin{array}{l}4.48-4.41 \mathrm{~m} \\
3.81 \mathrm{~d}(16.9)\end{array}$ & - & - \\
\hline
\end{tabular}


Table 1. Cont.

\begin{tabular}{|c|c|c|c|c|}
\hline \multirow{2}{*}{ Position } & \multicolumn{2}{|c|}{ 9-O-Demethylmaritidine (21) ${ }^{a}$} & \multicolumn{2}{|c|}{ 7-Oxonorpluviine (24) ${ }^{b}$} \\
\hline & $\delta_{\mathrm{C}}$ & $\delta_{\mathbf{H}}(J$ in $\mathbf{H z})$ & $\delta_{\mathrm{C}}$ & $\delta_{\mathbf{H}}(J$ in $\mathrm{Hz})$ \\
\hline $6 a$ & 123.9 & & - & - \\
\hline 7 & 109.2 & $6.51 \mathrm{~s}$ & 167.6 & \\
\hline $7 \mathrm{a}$ & - & - & 117.4 & \\
\hline 8 & 145.0 & & 117.3 & $7.45 \mathrm{~s}$ \\
\hline 9 & 144.0 & & 148.1 & \\
\hline 10 & 108.5 & $6.88 \mathrm{~s}$ & 154.5 & \\
\hline $10 \mathrm{a}$ & 138.2 & & - & - \\
\hline $10 \mathrm{~b}$ & 44.0 & & - & - \\
\hline 11 & 44.9 & $2.25-2.05 \mathrm{~m}$ & 111.1 & $6.99 \mathrm{~s}$ \\
\hline $11 \mathrm{a}$ & - & - & 136.5 & \\
\hline $11 b$ & 53.2 & $\begin{array}{l}3.50-3.42 \mathrm{~m} \\
2.98-2.90 \mathrm{~m}\end{array}$ & 41.9 & $2.84 \mathrm{dd}(10.3,2.2)$ \\
\hline $11 c$ & - & - & 60.9 & $3.53-3.47 \mathrm{~m}$ \\
\hline $\mathrm{C} 8-\mathrm{OCH}_{3}$ & 55.9 & $3.84 \mathrm{~s}$ & - & - \\
\hline $\mathrm{C} 10-\mathrm{OCH}_{3}$ & - & - & 56.7 & $3.98 \mathrm{~s}$ \\
\hline
\end{tabular}

\subsection{Cytotoxic Study of Isolated Amaryllidaceae Alkaloids}

A set of cell lines derived from various human tumor histotypes (leukemia-Jurkat, MOLT-4; adenocarcinomas of lung-A549, colon-HT-29, pancreas—PANC-1, cervix-HeLa, breast-MCF-7; ovarian carcinoma-A2780, and osteogenic sarcoma-SAOS-2) was used to screen the cytotoxic activity of all isolated compounds which had not been previously studied and were obtained in sufficient quantities. Normal human fetal lung fibroblasts (MRC-5) were used to study effect on non-tumorigenic cells. Growth-inhibitory activity of tested alkaloids was determined at a dose of $10 \mu \mathrm{M}$ (Table 2) using the WST-1 mitochondrial dehydrogenase activity assay.

Table 2. Cytotoxic activity of alkaloidal extract of N. cv. Professor Einstein (concentration $50 \mu \mathrm{g} \cdot \mathrm{mL}^{-1}$ ), and isolated Amaryllidaceae alkaloids 1, 2, 7, 13, 16, 20, 21, 22, and 23 using a single dose (concentration of $10 \mu \mathrm{M})$. WST-1 metabolic activity assay was used to analyze cell growth $48 \mathrm{~h}$ after treatment. The results are expressed as the mean values \pm SD of at least three independent experiments $(n=3)$. Cells treated with $1 \mu \mathrm{M}$ doxorubicin served as a positive control.

\begin{tabular}{|c|c|c|c|c|c|c|c|c|c|c|c|}
\hline $\begin{array}{l}\text { Cell } \\
\text { Type }\end{array}$ & Extract & 1 & 2 & 7 & 13 & 16 & 20 & 21 & 22 & 23 & Dox. \\
\hline Jurkat & $3 \pm 1$ & $76 \pm 5$ & $78 \pm 7$ & $102 \pm 9$ & $102 \pm 2$ & $102 \pm 4$ & $96 \pm 12$ & $97 \pm 6$ & $17 \pm 5$ & $100 \pm 10$ & $2 \pm 0$ \\
\hline A549 & $25 \pm 2$ & $109 \pm 22$ & $114 \pm 21$ & $107 \pm 8$ & $93 \pm 7$ & $110 \pm 10$ & $111 \pm 2$ & $104 \pm 7$ & $29 \pm 3$ & $109 \pm 9$ & $11 \pm 5$ \\
\hline HT-29 & $41 \pm 6$ & $110 \pm 17$ & $199 \pm 11$ & $98 \pm 7$ & $94 \pm 1$ & $103 \pm 5$ & $92 \pm 5$ & $89 \pm 10$ & $39 \pm 3$ & $106 \pm 8$ & $47 \pm 4$ \\
\hline PANC-1 & $34 \pm 3$ & $94 \pm 7$ & $100 \pm 5$ & $97 \pm 5$ & $100 \pm 3$ & $91 \pm 2$ & $84 \pm 1$ & $80 \pm 2$ & $52 \pm 13$ & $92 \pm 1$ & $78 \pm 3$ \\
\hline MCF-7 & $11 \pm 1$ & $98 \pm 9$ & $102 \pm 6$ & $95 \pm 7$ & $99 \pm 5$ & $96 \pm 7$ & $100 \pm 3$ & $91 \pm 3$ & $18 \pm 2$ & $102 \pm 8$ & $37 \pm 3$ \\
\hline SAOS-2 & $30 \pm 8$ & $98 \pm 4$ & $97 \pm 7$ & $102 \pm 4$ & $102 \pm 5$ & $103 \pm 4$ & $96 \pm 7$ & $95 \pm 4$ & $26 \pm 3$ & $103 \pm 4$ & $17 \pm 5$ \\
\hline MRC-5 & $29 \pm 6$ & $99 \pm 12$ & $97 \pm 4$ & $96 \pm 9$ & $108 \pm 4$ & $98 \pm 4$ & $92 \pm 4$ & $92 \pm 6$ & $39 \pm 3$ & $93 \pm 4$ & $29 \pm 3$ \\
\hline
\end{tabular}

The efficacy of each alkaloid in decreasing the growth of individual cell line, referred as the mean growth percentage (GP), was calculated as an average of all cell lines proliferation in percent. The 
threshold GP value for this screen was $<50 \%$ (50\% tumor growth inhibition), meaning good activity at $10 \mu \mathrm{M}$, as can be seen in the result for pancracine (22) in Table 2. Pancracine was able to inhibit all cancer cells used in the study, with the exception of PANC-1, where $\mathrm{IC}_{50}$ values ranged from 2.20 to $5.15 \mu \mathrm{M}$ (Table 3).

Table 3. $\mathrm{IC}_{50}$ values of pancracine and doxorubicin in human cancer and non-cancer cells ${ }^{\mathrm{a}, \mathrm{b}}$.

\begin{tabular}{ccc}
\hline Cell Type & Pancracine & Doxorubicin \\
\hline Jurkat & $5.07 \pm 0.31$ & $0.05 \pm 0.02$ \\
MOLT-4 & $2.71 \pm 0.25$ & $<0.01$ \\
A549 & $2.29 \pm 0.43$ & $0.43 \pm 0.06$ \\
HT-29 & $2.60 \pm 0.51$ & $0.77 \pm 0.24$ \\
A2780 & $5.08 \pm 0.43$ & $<0.01$ \\
HeLa & $5.03 \pm 0.36$ & $0.55 \pm 0.05$ \\
MCF-7 & $2.68 \pm 0.37$ & $0.44 \pm 0.10$ \\
SAOS-2 & $2.20 \pm 0.25$ & $0.1 \pm 0.17$ \\
MRC-5 & $5.15 \pm 0.34$ & $0.72 \pm 0.23$
\end{tabular}

a Results are expressed in $\mu \mathrm{M}$. ${ }^{\mathrm{b}}$ Results are the mean values \pm standard deviations of at least three independent replications.

Pancracine (22) is a montanine type of AA, in the same group as montanine, coccinine, and manthine. This structural type of AA seems to be a promising souce of compounds in the search for new anticancer drugs. They are characterized by a 5,11-methanomorphantridine ring system, the only differencies being the substitutions and configuration at C-2 and C-3 centers (Figure 3) [40]. Some of these compounds have been screened against different cancerous cells [12,41].<smiles>O[C@H]1C=C2[C@H]3C[C@H](O)OCOc4cc5c(cc4C[C@@H]53)CN2C[C@@H]1O</smiles>

Pancracine<smiles>CO[C@H]1C=C2[C@@H]3CN4[C@@H](OC)C[C@H]2C[C@H]1N4Cc1cc2c(cc13)OCO2</smiles>

Manthine

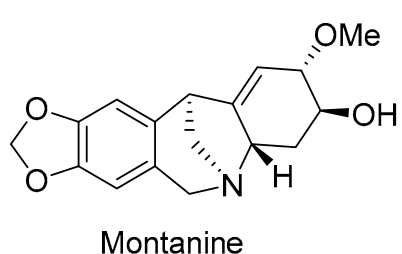<smiles>CO[C@H]1C=C2c3cc4c(cc3CN(C1)[C@@H]1C[C@H](O)[C@@H](O)C[C@@H]21)OCO4</smiles>

Figure 3. Structures of selected montanine-type Amaryllidaceae alkaloids.

Montanine and manthine showed strong in vitro growth inhibitory effect on three apoptosis-resistant cancer cell lines (A549, SKMEL-29, and U373) and three apoptosis-sensitive cancer cell lines (MCF7, Hs683, and B16F10) with $\mathrm{IC}_{50}$ values between 5 and $31 \mu \mathrm{M}$ [12]. In another recent study, $\mathrm{C}-2 \alpha-/ \mathrm{C}-2 \beta$-methoxy isomers montanine and coccinine were found to significantly affect the proliferation of human breast, colon, lung, and melanoma cancer cell lines over $48 \mathrm{~h}$ of treatment. The obtained results revealed that montanine has a more promising cytotoxic activity $\left(\mathrm{IC}_{50}\right.$ values were $1.9 \pm 0.4 \mu \mathrm{M}$ for A549 cells, $6.8 \pm 0.5 \mu \mathrm{M}$ for HCT-15 cells, $23.2 \pm 1.9 \mu \mathrm{M}$ for SK-MEL-28 cells, $4.4 \pm 0.4 \mu \mathrm{M}$ for MCF-7 cells, and $3.4 \pm 0.9 \mu \mathrm{M}$ for MDA-MB-231 cells, $3.6 \pm 1.7 \mu \mathrm{M}$ for Hs578T cells) when compared with coccinine ( $\mathrm{IC}_{50}$ values were $5.9 \pm 0.8 \mu \mathrm{M}$ for A549 cells, $16.8 \pm 1.8 \mu \mathrm{M}$ for HCT-15 cells, $>50 \mu \mathrm{M}$ for SK-MEL-28 cells, $7.9 \pm 0.9 \mu \mathrm{M}$ for MCF-7 cells, $13.8 \pm 0.8 \mu \mathrm{M}$ for MDA-MB-231 cells, and $5.3 \pm 0.4 \mu \mathrm{M}$ for Hs578T cells) [42]. Although previous studies, as well as our work, have demonstrated that AA of the montanine type can effectively suppress viability and proliferation of 
human cancer cells, the molecular mechanism of this cytotoxic activity has not yet been fully explored and is still waiting to be described.

\section{Experimental}

\subsection{General Experimental Procedures}

All solvents were treated using standard techniques before use. All reagents were purchased from commercial sources (Sigma Aldrich, Prague, Czech Republic) and used without purification. The NMR spectra were obtained in $\mathrm{CDCl}_{3}$ and $\mathrm{CD}_{3} \mathrm{OD}$ at ambient temperature on a VNMR S500 (Varian, Palo Alto, CA, USA) spectrometer operating at $500 \mathrm{MHz}$ for ${ }^{1} \mathrm{H}$ and $125.7 \mathrm{MHz}$ for ${ }^{13} \mathrm{C}$. Chemical shifts were recorded as $\delta$ values in parts per million (ppm) and were indirectly referenced to tetramethylsilane (TMS) via the solvent signal $\left(\mathrm{CDCl}_{3}-7.26 \mathrm{ppm}\right.$ for ${ }^{1} \mathrm{H}$ and $77.0 \mathrm{ppm}$ for ${ }^{13} \mathrm{C} ; \mathrm{CD}_{3} \mathrm{OD}-3.30 \mathrm{ppm}$ for ${ }^{1} \mathrm{H}$ and $49.0 \mathrm{ppm}$ for ${ }^{13} \mathrm{C}$ ). Coupling constants $(J)$ are given in $\mathrm{Hz}$. For unambiguous assignment of ${ }^{1} \mathrm{H}$ and ${ }^{13} \mathrm{C}$ signals, 2D NMR experiments, namely gCOSY, gHSQC, gHMBC, and NOESY were measured using standard parameter settings and standard pulse programs provided by the producer of the spectrometer. HRMS were obtained with a Waters Synapt G2-Si hybrid mass analyzer of a quadrupole-time-of-flight (Q-TOF) type, coupled to a Waters Acquity I-Class UHPLC system. The EI-MS were obtained on an Agilent 7890A GC 5975 inert MSD operating in EI mode at $70 \mathrm{eV}$ (Agilent Technologies, Santa Clara, CA, USA). A DB- 5 column $(30 \mathrm{~m} \times 0.25 \mathrm{~mm} \times 0.25 \mu \mathrm{m}$, Agilent Technologies, USA) was used. The temperature program was: $100-180{ }^{\circ} \mathrm{C}$ at $15{ }^{\circ} \mathrm{C} / \mathrm{min}, 1 \mathrm{~min}$ hold at $180{ }^{\circ} \mathrm{C}$, $180-300{ }^{\circ} \mathrm{C}$ at $5{ }^{\circ} \mathrm{C} / \mathrm{min}$, and $5 \mathrm{~min}$ hold at $300^{\circ} \mathrm{C}$; detection range $\mathrm{m} / \mathrm{z} 40-600$. The injector temperature was $280^{\circ} \mathrm{C}$. The flow-rate of the carrier gas (helium) was $0.8 \mathrm{~mL} / \mathrm{min}$. A split ratio of 1:15 was used. TLC was carried out on Merck precoated silica gel 60 F254 plates. Compounds on the plate were observed under UV light (254 and $366 \mathrm{~nm}$ ) and visualized by spraying with Dragendorff's reagent.

\subsection{Plant Material}

Fresh bulbs of Narcissus cv. Professor Einstein were obtained from the herbal dealer Lukon Glads (Sadská, Czech Republic). The botanical identification was performed by Professor L. Opletal, CSc. A voucher specimen is deposited in the Herbarium of the Faculty of Pharmacy in Hradec Králové under number CUFPH-16130/AL-447.

\subsection{Extraction and Isolation of Alkaloids}

Fresh bulbs (34 kg) were cut, minced, and underwent comprehensive extraction with ethanol $(\mathrm{EtOH})(96 \%, v / v, 2 \times)$. Each portion (approximately $1.2 \mathrm{~kg}$ ) was boiled twice for $30 \mathrm{~min}$ under reflux. The combined extracts were filtered and evaporated under reduced pressure. The crude extract $(638 \mathrm{~g})$ was dissolved in $1.5 \mathrm{~L}$ of $5 \%$ hydrochloric acid $(\mathrm{HCl})$, filtered twice, and diluted with distilled water to $4.5 \mathrm{~L}$ at $\mathrm{pH}$ 1. The water solution was defatted with diethyl ether $\left(\mathrm{Et}_{2} \mathrm{O} ; 2 \times 4 \mathrm{~L}\right)$, alkalized with $10 \%$ $\mathrm{Na}_{2} \mathrm{CO}_{3}$ to $\mathrm{pH} 10$, and exhaustively extracted with chloroform $\left(\mathrm{CHCl}_{3} ; 4 \times 4 \mathrm{~L}\right)$. The organic phase was evaporated to give $58 \mathrm{~g}$ of dark brown residue. The purification process was repeated to give $32 \mathrm{~g}$ of concentrated alkaloidal residue (brown syrup). The obtained extract, which was Dragendorff positive, was fractionated by column chromatography on neutral $\mathrm{Al}_{2} \mathrm{O}_{3}$ (ACROSS, $2100 \mathrm{~g}$ ) deactivated with $6 \%$ of distilled water. The extract was eluted with light petrol enriched with $\mathrm{CHCl}_{3}$ (gradually from 30:70 to 80:20), then with $\mathrm{CHCl}_{3}$ gradually enriched with $\mathrm{EtOH}$ (from 1:99 to 50:50), and finally with pure EtOH. Fractions of $250 \mathrm{~mL}$ were collected and monitored by TLC, yielding 495 fractions, which were combined into 15 final fractions and analyzed by TLC and GC-MS.

Combined fractions I-III $(60 \mathrm{mg})$ were separated by preparative TLC (toluene:EtOAc: $\mathrm{Et}_{2} \mathrm{NH}$ 8:1:1, $1 \times)$ and gave three sub-fractions. Sub-fraction I-III/2 was recrystalized from an ethanol and chloroform mixture (1:1) to give masonine $(\mathbf{1}, 5 \mathrm{mg})$. Sub-fraction I-III/3 was further chromatographed by preparative TLC (toluene: $\left.\mathrm{Et}_{2} \mathrm{NH} 95: 5,1 \times\right)$ to give homolycorine $(2,6 \mathrm{mg})$. Fractions IV $(35 \mathrm{mg}$ ) and VI $(25 \mathrm{mg})$, based on TLC, contained no alkaloidal compound, and were not used for isolation of 
alkaloids. Preparative TLC of fraction V (50 mg; toluene:EtOAc: $\mathrm{Et}_{2} \mathrm{NH}$ 8:1:1, 1×) gave sub-fractions $\mathrm{V} / \mathbf{1}-\mathrm{V} / \mathbf{4}$. Sub-fraction $\mathrm{V} / \mathbf{3}$ was further chromatographed by preparative TLC (cyclohexane: $\mathrm{Et}_{2} \mathrm{NH}$ 9:1, $2 \times)$ to give ismine $(3,4 \mathrm{mg})$. Fraction VII $(1.69 \mathrm{~g})$ was chromatographed by preparative TLC (toluene:Et $\left.{ }_{2} \mathrm{NH} 95: 5,2 \times\right)$ to give sub-fractions VII/1-VII/4. Caranine $(4,7 \mathrm{mg})$ was obtained by subsequent TLC of sub-fraction VII/2 (201 mg). Sub-fraction VII/3 (350 mg) was subjected to repeated preparative TLC (cyclohexane: toluene: $\left.\mathrm{Et}_{2} \mathrm{NH} 50: 45: 5,2 \times\right)$ to give galanthamine $(5,35 \mathrm{mg}$ ), narwedine $(6,15 \mathrm{mg})$, and lycoraminone $(7,30 \mathrm{mg})$. Pluviine $(8,25 \mathrm{mg})$ was obtained from sub-fraction VII/4 $(150 \mathrm{mg})$ by crystallization from hot ethanol $(10 \mathrm{~mL})$. Fraction VIII $(30 \mathrm{mg})$ was subjected to preparative TLC (cyclohexane:isopropanol:Et ${ }_{2} \mathrm{NH}$ 77.5:15:7.5, $1 \times$ ) to give sub-fractions VIII/1-VIII/4. Sub-fraction VIII/2 (203 mg) was further chromatographed by preparative TLC (cyclohexane:Et $\left.{ }_{2} \mathrm{NH} 95: 5,2 \times\right)$ to give incartine (9, $5 \mathrm{mg})$, galanthine (10,6 mg), and lycoramine (11, $80 \mathrm{mg})$. Epinorgalanthamine $(\mathbf{1 2}, 10$ $\mathrm{mg}$ ) was obtained from VIII/4 by preparative TLC (cyclohexane:EtOAc:isopropanol:Et ${ }_{2} \mathrm{NH}$ 45:45:5:5, $2 \times)$. Fraction IX (138 mg) was chromatographed by preparative TLC (toluene:EtOAc: $\mathrm{Et}_{2} \mathrm{NH}$ 7:2.5:0.5, $1 \times)$ to give norlycoramine $(\mathbf{1 3}, 35 \mathrm{mg})$. Haemanthamine $(\mathbf{1 4}, 320 \mathrm{mg})$ was obtained from fraction $X$ $(1.02 \mathrm{~g})$ by crystallization from an ethanol and chloroform mixture (1:1). Hippeastrine $(\mathbf{1 5}, 166 \mathrm{mg})$ was obtained from fraction XI (616 mg) by crystallization from an ethanol and chloroform mixture (1:1). Mother liquor of fraction XI was subjected to preparative TLC (toluene:EtOAc:Et2NH 15:75:10, 1×) to give epimaritidine (16, $127 \mathrm{mg})$. Fraction XII (1.43 g) was dissolved in hot ethanol and lycorine (17, $752 \mathrm{mg}$ ) crystallized from the mixture. Tazzetine $(\mathbf{1 8}, 1.85 \mathrm{~g})$ crystallized (EtOH: $\mathrm{CHCl}_{3}$ 7:3, $100 \mathrm{~mL}$ ) from fraction XIII $(3.11 \mathrm{~g})$. The mother liquor $(890 \mathrm{mg})$ was chromatographed by preparative TLC (cyclohexane:acetone: $\mathrm{NH}_{3}$ 50:50:1, 3×) to give sub-fractions XIII/1-XIII/3. Subfraction XIII/1 (89 mg) was dissolved in hot ethanol and eugenine $(\mathbf{1 9}, 20 \mathrm{mg})$ crystallized from the solution. Fraction XIV $(6.5 \mathrm{~g})$, by column chromatography on $\mathrm{Al}_{2} \mathrm{O}_{3}(800 \mathrm{~g})$, yielded seven sub-fractions XIV/1-XIV/7. Subfraction XIV/6 was subjected to preparative TLC (cyclohexane:acetone: $\mathrm{NH}_{3}$ 10:80:1) to give norpluviine $(\mathbf{2 0}, 62$ $\mathrm{mg}$ ) and 9-O-demethylmaritidine (21, $15 \mathrm{mg})$. Subfraction XIV/7 (2.5 g) was subjected to preparative TLC (toluene:acetone:EtOH: $\mathrm{NH}_{3}$ 40:40:6:4, 2×) to obtain pancracine $(\mathbf{2 2}, 247 \mathrm{mg}$ ) and subfraction XIV/7-B (1.95 g). 9-O-Demethylhomolycorine (23, $1.42 \mathrm{~g}$ ) was obtained from sub-fraction XIV/7-B by preparative TLC (toluene: $\left.\mathrm{Et}_{2} \mathrm{NH}, 95: 5,3 \times\right)$. Fraction XV $(672 \mathrm{mg}$ ) was separated by preparative TLC (EtOAc:MeOH:Et ${ }_{2} \mathrm{NH}$ 8:1:1, 1×) into four sub-fractions, XV/1-XV/4. Sub-fraction XV/3 was further chromatographed by preparative TLC to give 7-oxonorpluviine (24, $6 \mathrm{mg})$.

\subsection{In Vitro Cytotoxicity Study}

\subsubsection{Cell Culture and Culture Conditions}

Selected human tumor and non-tumor cell lines Jurkat (acute T cell leukemia), MOLT-4 (acute lymphoblastic leukemia), A549 (lung carcinoma), HT-29 (colorectal adenocarcinoma), PANC-1 (pancreas epithelioid carcinoma), A2780 (ovarian carcinoma), HeLa (cervix adenocarcinoma), MCF-7 (breast adenocarcinoma), SAOS-2 (osteosarcoma), and MRC-5 (normal lung fibroblasts) were purchased from either ATCC (Manassas, VA, USA) or Sigma-Aldrich (St. Louis, MO, USA) and cultured according to the providers' culture method guidelines. All cell lines were maintained at $37^{\circ} \mathrm{C}$ in a humidified $5 \%$ carbon dioxide and $95 \%$ air incubator. Cells in the maximum range of either 10 passages for a primary cell line (MRC-5), or in the maximum range of 20 passages for cancer cell lines (Jurkat, MOLT-4, A549, HT-29, PANC-1, A2780, HeLa, MCF-7, and SAOS-2) and in an exponential growth phase were used for this study.

\subsubsection{Cell Treatment}

All the alkaloids evaluated and doxorubicin, used as positive control, were dissolved in dimethyl sulfoxide (DMSO) (Sigma-Aldrich, St. Louis, MO, USA) to prepare stock solutions with a concentration of 10-50 mM based on their solubility. Stock solutions were freshly prepared before use in the experiments. For the experiments, the stock solutions were diluted with the appropriate culture 
medium to create final concentrations $(10 \mu \mathrm{M}$ for a single-dose alkaloid cytotoxicity screen and $1 \mu \mathrm{M}$ for doxorubicin, used as a reference compound) making sure that the concentration of DMSO was $<0.1 \%$ to avoid toxic effects on the cells. Control cells were sham-treated with a DMSO vehicle only (0.1\%; control).

\subsubsection{WST-1 Cytotoxicity Assay}

The WST-1 (Roche, Mannheim, Germany) reagent was used to determine the cytostatic effect of the test compounds. WST-1 is designed for the spectrophotometric quantification of cell proliferation, growth, viability, and chemosensitivity in cell populations using a 96 well plate format (Sigma, St. Louis, MO, USA). The principle of WST-1 is based on photometric detection of the reduction of tetrazolium salt to a colored formazan product. The cells were seeded at a previously established optimal density (30,000 Jurkat, 25,000 MOLT-4, 500 A549, 1500 HT-29, 2000 PANC-1, 5000 A2780, 500 HeLa, 1500 MCF-7, 2000 SAOS-2, and 2000 MRC-5 cells/well) in $100 \mu \mathrm{L}$ of culture medium, and adherent cells were allowed to reattach overnight. Thereafter, the cells were treated with $100 \mu \mathrm{L}$ of either corresponding alkaloids or doxorubicin stock solutions to obtain the desired concentrations and incubated in $5 \% \mathrm{CO}_{2}$ at $37^{\circ} \mathrm{C}$. WST-1 reagent diluted 4-fold with PBS $(50 \mu \mathrm{L})$ was added $48 \mathrm{~h}$ after treatment. Absorbance was measured after $3 \mathrm{~h}$ incubation with WST-1 at $440 \mathrm{~nm}$. The measurements were performed in a Tecan Infinite M200 spectrometer (Tecan Group, Männedorf, Switzerland). All experiments were performed at least three times with triplicate measurements at each drug concentration per experiment. The viability was quantified as described in Havelek et al. according to the following formula: (\%) viability $=($ Asample - Ablank $) /($ Acontrol - Ablank $) \times 100$, where A is the absorbance of the employed WST-1 formazan measured at $440 \mathrm{~nm}$ [43]. The viability of the treated cells was normalized to the viability of cells treated with $0.1 \%$ DMSO (Sigma-Aldrich, St. Louis, MO, USA) as a vehicle control.

\subsection{Statistical Analysis}

The descriptive statistics of the results were calculated and the charts made in either Microsoft Office Excel 2010 (Microsoft, Redmond, WA, USA) or GraphPad Prism 5 biostatistics (GraphPad Software, La Jolla, CA, USA). In this paper, all of the values have been expressed as arithmetic means with SD of triplicates $(n=3)$, unless otherwise noted. The significant differences between the groups were analyzed using Student's t-test and a $p$ value $\leq 0.05$ was considered statistically significant. IC $_{50}$ curves of pancracine and standard cytostatic treatment doxorubicin were generated and values of $\mathrm{IC}_{50}$ were deducted with GraphPad Prism 5 Biostatistics.

\section{Conclusions}

In conclusion, 24 Amaryllidaceae alkaloids of various structural types were isolated from fresh bulbs of Narcissus cv. Professor Einstein. The constitution of a newly isolated alkaloid, 7-oxopluviine, was structurally determined. The complete NMR data for 9-O-demethylmaritidine are reported. Isolated compounds not previously studied for cytotoxicity were assayed for their cytotoxicity on a set of nine human cancer cells of different histotypes. This study revealed promising cytotoxic activity of pancracine, a montanine-type alkaloid, which was isolated in an amount that will allow more detailed cytotoxic studies in the future, and also the preparation of semisynthetic derivatives. Taken together, the plant cultivar Narcissus cv. Professor Einstein is as a rich source of diverse alkaloids, some of which show interesting activities for further pharmaceutical research.

Supplementary Materials: The following are available online at http://www.mdpi.com/2223-7747/9/2/137/s1: Figure S1 GS/MS analysis of alkaloidal extract of Narcissus cv. Professor Einstein, Table S1 Alkaloids identified by GC/MS in fresh bulbs of Narcissus cv. Professor Einstein, Figure S2- ${ }^{1} \mathrm{H}$ NMR spectra of 9-O-demethylmaritidine (21) in $\mathrm{CDCl}_{3}$, Figure S2-2 ${ }^{13} \mathrm{C}$ NMR spectra of 9-O-demethylmaritidine (21) in $\mathrm{CDCl}_{3}$, Figure S3-1 ESI-HRMS spectra of new alkaloid 7-oxonorpluviine (24), Figure S3-2 ${ }^{1} \mathrm{H}$ NMR spectra of new alkaloid 7-oxonorpluviine (24) in $\mathrm{CD}_{3} \mathrm{OD}$, Figure S3-3 ${ }^{13} \mathrm{C}$ NMR spectra of new alkaloid 7-oxonorpluviine (24) in $\mathrm{CD}_{3} \mathrm{OD}$, Figure S3-4 gCOSY spectra of new alkaloid 7-oxonorpluviine (24) in $\mathrm{CD}_{3} \mathrm{OD}$, Figure S3-5 gHSQC spectra of new alkaloid 
7-oxonorpluviine (24) in $\mathrm{CD}_{3} \mathrm{OD}$, Figure S3-6 gHMBC spectra of new alkaloid 7-oxonorpluviine (24) in $\mathrm{CD}_{3} \mathrm{OD}$, Figure S3-7 NOESY spectra of new alkaloid 7-oxonorpluviine (24) in $\mathrm{CD}_{3} \mathrm{OD}$.

Author Contributions: K.B., A.H., L.O. contributed to the isolation of Amaryllidaceae alkaloids. K.B., J.M., J.K., A.H., and J.J. assisted with the identification of the isolated alkaloids (MS, NMR, etc.). D.K., R.H., M.M., and M.ř were involved with the cytotoxicity assays. L.C. and M.ř. designed the study, supervised the laboratory work and contributed to the critical reading of the manuscript. All of the authors read the final manuscript and approved the submission. All authors have read and agreed to the published version of the manuscript.

Funding: Research reported in this publication was supported by projects of Charles University (No. SVV UK 260 412; 260 401; Progres/UK Q40-01 and Q42), by MH CZ-DRO (University Hospital Hradec Kralove, No. 00179906), by Long-term development plan (Faculty of Military Health Sciences), and by the Pre-application research into innovative medicines and medical technologies project (Reg. No. CZ.02.1.01/0.0/0.0/18_069/0010046) co-funded by the European Union.

Acknowledgments: The authors wish to thank Gerald Blunden for critical reading of the manuscript and corrections of English, and to Lucie Nováková for measurement of the HRMS spectra of the new compound.

Conflicts of Interest: The authors declare no conflict of interest.

\section{References}

1. Ingrassia, L.; Lefranc, F.; Mathieu, V.; Darro, F.; Kiss, R. Amaryllidaceae isocarbostyril alkaloids and their derivatives as promising antitumor agents. Transl. Oncol. 2008, 1, 1-13. [CrossRef] [PubMed]

2. Havelek, R.; Muthna, D.; Tomsik, P.; Kralovec, K.; Seifrtova, M.; Cahlikova, L.; Hostalkova, A.; Safratova, M.; Perwein, M.; Cermakova, E.; et al. Anticancer potential of Amaryllidaceae alkaloids evaluated by screening with a panel of human cells, real-time cellular analysis and Ehrlich tumor-bearing mice. Chem. Biol. Interact. 2017, 275, 121-132. [CrossRef] [PubMed]

3. Nair, J.J.; van Standen, J. Cytotoxicity studies of lycorine alkaloids of the Amaryllidaceae. Nat. Prod. Commun. 2014, 9, 1193-1210. [CrossRef] [PubMed]

4. Cho, N.; Du, Y.; Valenciano, A.L.; Fernandez-Murga, M.L.; Goetz, M.; Clement, J.; Cassera, M.B.; Kingston, D.G.I. Antiplasmodial alkaloids from bulbs of Amaryllis belladonna Steud. Bioor. Med. Chem. Lett. 2018, 28, 40-42. [CrossRef] [PubMed]

5. Zhan, G.; Zhou, J.; Liu, R.; Liu, T.; Guo, G.; Wang, J.; Xiang, M.; Xue, Y.; Luo, Z.; Zhang, Y.; et al. Galanthamine, plicamine, and secoplicamine alkaloids from Zephyranthes candida and their anti-acetylcholinesterase and antiinflammatory activities. J. Nat. Prod. 2016, 79, 760-766. [CrossRef]

6. Locarek, M.; Novakova, J.; Kloucek, P.; Hostalkova, A.; Kokoska, L.; Gabrlova, L.; Safratova, M.; Opletal, L.; Cahlikova, L. Antifugal and antibacterial activity of extracts and alkaloids of selected Amaryllidaceae plant species. Nat. Prod. Commun. 2015, 10, 1537-1540.

7. Hulcova, D.; Maříkova, J.; Korabecny, J.; Hostalkova, A.; Jun, D.; Kunes, J.; Chlebek, J.; Opletal, L.; De Simone, A.; Novakova, L.; et al. Amaryllidaceae alkaloids from Narcissus pseudonarcissus L. cv. Dutch Master as potential drugs in treatment of Alzheimer's disease. Phytochemistry 2019, 165, 112055. [CrossRef]

8. Castillo-Ordonez, W.O.; Tamarozzi, E.R.; da Silva, G.M.; Aristizabal-Pachon, A.F.; Sakamoto-Hojo, E.T.; Takahashi, C.S.; Giuliatti, S. Exploration of the acetylcholinesterase inhibitory activity of some alkaloids from Amaryllidaceae family by molecular docking in silico. Neurochem. Res. 2017, 42, 2826-2830. [CrossRef]

9. Jin, Z. Amaryllidaceae and Sceletium alkaloids. Nat. Prod. Rep. 2007, 24, 886-905. [CrossRef]

10. Safratova, M.; Hostalkova, A.; Hulcova, D.; Breiterova, K.; Hrabcova, V.; Machado, M.; Fontinha, D.; Prudêncio, M.; Kunes, J.; Chlebek, J.; et al. Alkaloids from Narcissus poeticus cv. Pink Parasol of various structural types and their biological activity. Arch. Pharm. Res. 2018, 41, 208-218. [CrossRef]

11. Maelicke, A.; Samochocki, M.; Jostock, R.; Fehrenbacher, A.; Ludwig, J.; Albuquerque, E.X.; Zerlin, M. Allosteric sensitization of nicotinic receptors by galanthamine, a new treatment strategy for Alzheimer's disease. Biol. Psychiatry 2001, 49, 279-288. [CrossRef]

12. Govindaraju, K.; Ingels, A.; Hasan, M.N.; Sun, D.; Mathieu, V.; Masi, M.; Evidente, A.; Kornienko, A. Synthetic analogues of the montanine-type alkaloids with activity against apoptosis-resistant cancer cells. Bioorg. Med. Chem. Lett. 2018, 28, 589-593. [CrossRef] [PubMed]

13. Evidente, A.; Kireev, A.S.; Jenkins, A.R.; Romero, A.E.; Steelant, W.F.; Van Slambrouck, S.; Kornienko, A. Biological evaluation of structurally diverse Amaryllidaceae alkaloids and their synthetic derivatives: Discovery of novel leads for anticancer drug design. Planta Med. 2009, 75, 501-507. [CrossRef] [PubMed] 
14. Ingrassia, L.; Lefranc, F.; Dewelle, J.; Pottier, L.; Mathieu, V.; Spiegl-Kreinecker, S.; Sauvage, S.; El Yazidi, M.; Dehoux, M.; Berger, W.; et al. Structure-activity relationship analysis of novel derivatives of narciclasine (an Amaryllidaceae isocarbostyril derivative) as potential anticancer agents. J. Med. Chem. 2009, 52, 1100-1114. [CrossRef] [PubMed]

15. Havelek, R.; Seifrtova, M.; Kralovec, K.; Bruckova, L.; Cahlikova, L.; Dalecka, M.; Vavrova, J.; Rezacova, M.; Opletal, L.; Bilkova, Z. The effect of Amaryllidaceae alkaloids haemanthamine and haemanthidine on cell cycle progression and apoptosis in p53-negative human leukemic Jurkat cells. Phytomedicine 2014, 21, 479-490. [CrossRef] [PubMed]

16. Li, L.; Zhang, Z.; Yang, Q.; Ning, M. Lycorine inhibited the cell growth of non-small cell lung cancer by modulating the miR-186/CDK1 axis. Life Sci. 2019, 231, 116528. [CrossRef] [PubMed]

17. Breiterova, K.; Locarek, M.; Kohelova, E.; Talackova, M.; Hulcova, D.; Opletal, L.; Cahlikova, L. Daffodils as potential crops of biologically-active compounds: Assessment of 40 ornamental taxa for their alkaloid profile and cholinesterases inhibition activity. Nat. Prod. Commun. 2018, 13, 419-422. [CrossRef]

18. Kornienko, A.; Evidente, A. Chemistry, biology, and medicinal potential of narciclasine and its congeners. Chem. Rev. 2008, 108, 1982-2014. [CrossRef]

19. Hartwell, J.L. Plants used against cancer. A survey. Lloydia 1967, 30, 379-436.

20. Kington, S. The International Daffodil Register and Classified List; Royal Horticultural Society: London, UK, 2008.

21. Pettit, G.R.; Tan, R.; Bao, G.-H.; Melody, N.; Doubek, D.L.; Gao, S.; Chapuis, J.-C.; Williams, L. Antineoplastic agents. 587. Isolation and structure of 3-epipancratistatin from Narcissus cv. Ice Follies. J. Nat. Prod. 2012, 75, 771-773. [CrossRef]

22. Pigni, N.B.; Ríos-Ruiz, S.; Martínez-Francés, V.; Nair, J.J.; Viladomat, F.; Codina, C.; Bastida, J. Alkaloids from Narcissus serotinus. J. Nat. Prod. 2012, 75, 1643-1647. [CrossRef] [PubMed]

23. Huang, S.; Zhang, Y.; He, H.; Li, S.; Tang, G.; Chen, D.; Cao, M.; Di, Y.; Hao, X.J. A new Amaryllidaceae alkaloid from bulbs of Lycoris radiata. Chin. J. Nat. Med. 2013, 11, 406-410. [CrossRef] [PubMed]

24. Cowden, C.J.; Banwell, M.G.; Ho, I.C.S. Synthesis of putative structure of 5,6-dihydrobicolorin. J. Nat. Prod. 1994, 57, 1746-1750. [CrossRef]

25. Lamoral-Theys, D.; Andolfi, A.; Van Goietsenoven, G.; Cimmino, A.; Le Calvé, B.; Wauthoz, N.; Mégalizzi, V.; Gras, T.; Bruyere, C.; Dubois, J.; et al. Lycorine, the main phenanthridine Amaryllidaceae alkaloid, exhibits significant antitumor activity in cancer cells that display resistance to proapoptotic stimuli: An investigation of structure-activity relationship and mechanistic insight. J. Med. Chem. 2009, 52, 6244-6625. [CrossRef] [PubMed]

26. Chen, J.-Q.; Xie, J.-H.; Bao, D.-H.; Liu, S.; Zhou, Q.-L. Total synthesis of (-)-galanthamine and (-)-lycoramine via catalytic asymmetric hydrogenation and intramolecular reductive Heck cyclization. Org. Lett. 2012, 14, 2714-2717. [CrossRef] [PubMed]

27. Jegorov, A.; Buchta, M.; Sedmera, P.; Kuzma, M.; Havlicek, V. Accurate product ion mass spectra of galanthamine derivatives. J. Mass. Spectrom. 2006, 41, 544-548. [CrossRef] [PubMed]

28. Lee, T.B.K.; Goehring, K.E.; Ma, Z. One-Step conversion of galanthamine to lycoraminone: A novel hydride-transfer reaction. J. Org. Chem. 1998, 63, 4535-4538. [CrossRef]

29. Berkov, S.; Reyes-Chilpa, R.; Codina, C.; Viladomat, F.; Bastida, J. Revised NMR data for incartine: An alkaloid from Galanthus elwesii. Molecules 2007, 12, 1430-1435. [CrossRef]

30. Berkov, S.; Bastida, J.; Sidjimova, B.; Viladomat, F.; Codina, C. Phytochemical differentiation of Galanthus nivalis and Galanthus elwesii (Amaryllidaceae): A case study. Biochem. Syst. Ecol. 2008, 36, 638-645. [CrossRef]

31. Bastida, J.; Viladomat, F.; Bergonon, S.; Fernandez, J.M.; Codina, C.; Rubiralta, M.; Quirion, J.-C. Alkaloids from Narcissus leonensis. Phytochemistry 1993, 34, 1656-1658. [CrossRef]

32. Bastida, J.; Lavilla, R.; Viladomat, F. The Alkaloids: Chemical and biological aspects of Narcissus alkaloids. In The Alkaloids: Chemistry and Biology; Cordell, G.A., Ed.; Elsevier: Amsterdam, The Netherlands, 1998; Volume 63, pp. 87-179.

33. Jeffs, P.W.; Abou-Donia, A.; Campau, D. Structures of 9-O-demethylhomolycorine and $5 \alpha$-hydroxyhomolycorine. alkaloids of Crinum defixum, C. scabrum, and C. latifolium. Assignment of aromatic substitution patterns from 1H-coupled 13C spectra. J. Org. Chem. 1985, 50, 1732-1737. [CrossRef]

34. Ghosal, S.; Ashutosh Razdan, S. (+)-Epimaritidine, an alkaloid from Zephyranthes rosea. Phytochemistry 1985, 24, 635-637. [CrossRef] 
35. Berkov, S.; Sidjimove, B.; Evstatieva, L.; Popov, S. Intraspecific variability in the alkaloid metabolism of Galanthus elwesii. Phytochemistry 2004, 65, 579-586. [CrossRef] [PubMed]

36. Pham, L.H.; Gründemann, E.; Wagner, J.; Bartoszek, M.; Döpke, W. Two novel Amaryllidaceae alkaloids from Hippeastrum equestre Herb.: 3-O-demethyltazettine and egonine. Phytochemistry 1999, 51, 327-332. [CrossRef]

37. Via, J.; Arriortura, M.I.; Ochando, L.E.; Reventos, M.M.; Amigo, J.M.; Bastida, J. Structure of eugenine, an alkaloid from Narcissus eugeniae. Acta Cryst. C 1989, 45, 2020-2022. [CrossRef]

38. Berkov, S.; Romani, S.; Herrera, M.; Viladomat, F.; Codina, C.; Momekov, G.; Ionkova, I.; Bastida, J. Antiproliferative alkaloids from Crinum zeylanicum. Phytother. Res. 2011, 25, 1686-1692. [CrossRef]

39. Bastida, J.; Llabrés, J.M.; Viladomat, F.; Codina, C.; Rubiralta, M.; Feliz, M. 9-O-Demethylmaritidine: A new alkaloid from Narcissus radinganorum. Planta Med. 1988, 54, 524-526. [CrossRef]

40. Bao, X.; Cao, Y.-X.; Chu, W.-D.; Qu, H.; Du, J.-Y.; Zhao, X.-H.; Ma, X.-Y.; Wang, C.-T.; Fan, C.-A. Bioinspired total synthesis of montanine-type Amaryllidaceae alkaloids. Angew. Chem. Int. Edit. 2013, 52, 14167-14172. [CrossRef]

41. Farinon, M.; Clarimundo, V.S.; Pedrazza, G.P.; Gulko, P.S.; Zuanazzi, J.A.; Xavier, R.M.; de Oliveira, P.G. Disease modifying anti-rheumatic activity of the alkaloid montanine on experimental arthritis and fibroblast-like synoviocytes. Eur. J. Pharmacol. 2017, 15, 180-187. [CrossRef]

42. Masi, M.; van Slambrouck, S.; Gunawardana, S.; van Rensburg, M.J.; James, P.C.; Mochel, J.G.; Heliso, P.S.; Albalawi, A.S.; Cimmino, A.; van Otterlo, W.A.L.; et al. Alkaloids isolated from Haemanthus humilis Jacq., an indigenous South African Amaryllidaceae: Anticancer activity of coccinine and montanine. S. Afr. J. Bot. 2019, 126, 277-281. [CrossRef]

43. Havelek, R.; Siman, P.; Cmielova, J.; Stoklasova, A.; Vavrova, J.; Vinklarek, J.; Knizek, J.; Rezacova, M. Differences in vanadocene dichloride and cisplatin effect on MOLT-4 leukemia and human peripheral blood mononuclear cells. Med. Chem. 2012, 8, 615-621. [CrossRef] [PubMed]

(C) 2020 by the authors. Licensee MDPI, Basel, Switzerland. This article is an open access article distributed under the terms and conditions of the Creative Commons Attribution (CC BY) license (http://creativecommons.org/licenses/by/4.0/). 